\title{
BioOne enesencen

\section{West Nile Virus Survey of Birds, Horses, and Mosquitoes of the Pacific Coast, Southern Mexico}

Author(s): Antonio J. Cortés-Guzmán , Rosa María Sánchez-Casas , Luis A. Ibarra-Juárez, Aldo I. Ortega-Morales , Julián E. GarciaRejón, Juan F. Contreras-Cordero, Pedro Mis-Ávila , Marco A. Domínguez-Galera, Eduardo E. Rebollar-Téllez, Carlos E. Medina De la Garza and Ildefonso Fernández-Salas

Source: Southwestern Entomologist, 38(2):231-240. 2013.

Published By: Society of Southwestern Entomologists

DOI: http://dx.doi.org/10.3958/059.038.0208

URL: http://www.bioone.org/doi/full/10.3958/059.038.0208

BioOne (www.bioone.org) is a nonprofit, online aggregation of core research in the biological, ecological, and environmental sciences. BioOne provides a sustainable online platform for over 170 journals and books published by nonprofit societies, associations, museums, institutions, and presses.

Your use of this PDF, the BioOne Web site, and all posted and associated content indicates your acceptance of BioOne's Terms of Use, available at www.bioone.org/page/terms_of_use.

Usage of BioOne content is strictly limited to personal, educational, and non-commercial use. Commercial inquiries or rights and permissions Bio pequests should beodireeted toin the indilividutal publishier as teopyrighe hioldethors, nonprofit publishers, academic institutions, research libraries, and research funders in the common goal of maximizing access to critical research. 


\section{West Nile Virus Survey of Birds, Horses, and Mosquitoes of the Pacific Coast, Southern Mexico}

Antonio J. Cortés-Guzmán ${ }^{1}$, Rosa María Sánchez-Casas ${ }^{1,6}$, Luis A. Ibarra-Juárez ${ }^{2}$, Aldo I. Ortega-Morales ${ }^{3}$, Julián E. Garcia-Rejón $n^{4}$, Juan F. Contreras-Cordero ${ }^{7}$, Pedro Mis-Ávila ${ }^{5}$, Marco A. Domínguez-Galera ${ }^{5}$, Eduardo E. Rebollar-Téllez ${ }^{1}$, Carlos E. Medina De la Garza ${ }^{6}$, and Ildefonso Fernández-Salas ${ }^{1,6}$

Abstract. Serology of West Nile virus vectors and non-human reservoirs was surveyed at Acapulco, Jose Azueta, and Ometepec, three Pacific Coast localities of Guerrero State, Mexico. The objectives of this study were to use enzyme-linked immnosorbent assay (ELISA) to assess West Nile virus antibodies of bird and equine serum samples and use reverse transcription of polymerase chain reaction (RT-PCR) to detect the virus in field-collected resting mosquitoes. Forty birds trapped using mist nets yielded $10 \%$ seroprevalence. Similarly, $18.6 \%$ of 102 equine blood samples had West Nile virus. In addition, 4,854 mosquitoes were caught using motorized backpack aspirators and grouped into 116 pools. Of the 16 species and seven genera, no mosquito was positive for West Nile virus. Our study demonstrated West Nile virus seroprevalence on resident birds and equines in Guerrero State, Mexico.

\section{Introduction}

West Nile Virus is a member of the Flavivirus genus (Flaviviridae). The flaviviruses have positive-sense, single-stranded RNA (Calisher and Gould, 2003, Lindenbach et al. 2007). West Nile virus can cause febrile illness, meningitis, encephalitis, and flaccid paralysis (Hayes et al. 2005). It was first isolated from a febrile woman in Uganda in 1937 (Smithburn et al. 1940) and subsequently associated with sporadic cases of disease and major outbreaks in Africa, Australia, Eurasia, and the Middle East (Kramer et al. 2008, et al. 2010). The current epizootic/epidemic of West Nile virus in North America seems to be the result of a single introduction into the New York City area in 1999 (Lanciotti et al. 1999, Ebel et al. 2001), followed by rapid expansion of the range that currently encompasses the contiguous United States, Canada, Mexico, Central America, Caribbean, and South

\footnotetext{
${ }^{1}$ Laboratorio de Entomología Médica, Facultad de Ciencias Biológicas, Universidad Autónoma de Nuevo León, San Nicolás de los Garza, Nuevo León, México.

${ }^{2}$ Departamento de Genómica Alimentaria Universidad de la Ciénega de Michoacán de Ocampo, Sahuayo, Michoacán.

${ }^{3}$ Laboratorio de Entomología, Universidad Agraria Antonio Narro.

${ }^{4}$ Laboratorio de Arbovirología, Universidad Autónoma de Yucatán, Mérida.

${ }^{5}$ Secretaria de Salud del Estado de Quintana Roo, Cancún, Quintana Roo.

${ }^{6}$ Universidad Autónoma de Nuevo León, Centro de Investigación y Desarrollo en Ciencias de la Salud, Unidad de Patógenos Emergentes, Monterrey, Nuevo León, México.

${ }^{7}$ Laboratorio de Inmunología y Virología, Facultad de Ciencias Biológicas, Universidad Autónoma de Nuevo León.
} 
America (Hayes et al. 2005, Komar and Clark 2006, Morales et al. 2006, Bosch et al. 2007). The first evidence of West Nile virus in northern Mexico occurred in 2002 when antibodies were detected in horses, Equus ferus caballus L., in the states of Chihuahua, Coahuila, and Tamaulipas (Blitvich et al. 2003a, Estrada-Franco et al. 2003). Serological evidence of West Nile virus has been reported in almost every Mexican state (Komar and Clark, 2006, Blitvich 2008). However, only 11 human cases of West Nile virus disease have been reported in Mexico. These cases occurred in the states of Chihuahua, Nuevo Leon, Oaxaca, and Sonora (ElizondoQuiroga et al. 2005, Komar and Clark, 2006, Blitvich, 2008, Rios-lbarra et al. 2010, CONAVE 2012). Several species of mosquitoes have been reported to be infected with West Nile virus in Mexico, including Culex nigripalpus (Theobald) and Cx. interrogator (Dyar and Knab) in Chiapas State, Cx. tarsalis (Coquillett) in Baja California State, and Cx. quinquefasciatus (Say) in Nuevo Leon State (ElizondoQuiroga et al. 2005, Medina et al. 2008, Ulloa et al. 2009, Ibarra-Juarez et al. 2012). Most epidemiological West Nile virus studies from Mexico focused mainly on the northern Mexico-USA border and some states along the Gulf of Mexico and Caribbean. Most of the Pacific Coast states have not been thoroughly surveyed despite being in the Central and Pacific flyways of North American birds (BirdLife International 2012a,b). This study assessed the zoonotic circulation of West Nile virus among mosquito vectors, equines, and resident and migratory birds in rural localities of Guerrero State on the southern Pacific Coast of Mexico.

\section{Materials and Methods}

Study Area. The state of Guerrero is between 16 $16^{\circ} 48^{\prime \prime}$ and $18^{\circ} 53^{\prime} 12^{\prime \prime}$ north latitude and, $98^{\circ} 00^{\prime} 13^{\prime \prime}$ and $102^{\circ} 11^{\prime} 44^{\prime \prime}$ west longitude in the Sierra Madre del Sur. Guerrero is bordered by Mexico, Michoacan, Morelos, and Puebla states to the north, Oaxaca and Puebla to the east, Michoacan to the west, and Oaxaca and the Pacific Ocean to the south. The Guerrero coastline is a tropical rainforest 500 $\mathrm{km}$ long. In Guerrero, the rainy season is early June to mid-September, with 632$2,000 \mathrm{~mm}$ of rainfall per year. The average annual temperature during the last 20 years was $27-29^{\circ} \mathrm{C}$ (Gobierno del Estado de Guerrero 2012). The study area belongs to the Mexican province and the climate classification system of Köppen modified by García (1981) defined as warm-subhumid with summer rains (Aw, wi) and $5-10 \%$ winter rain. The study area includes the coastline municipalities of Acapulco, Jose Azueta en Ometepec (Fig. 1). The locations were selected based on abundance of aquatic habitat such as wetlands, marshes, brackish water lagoons, and mangroves.

Samples from Birds and Equines. From November 2007 to October 2008, a single trapping by strategically placed mist nets was used to catch birds in each municipality. Four nets were used during 3 days at each site and checked every 2 hours during daylight hours (Ralph et al. 1996). Birds were identified according to species and migratory or resident status (Vried 1988, Peterson and Chalif 1993, Kaufman et al. 2005). Caught birds were bled from the jugular or ulnar vein, and blood samples immediately five-fold diluted using field diluent (sterile phosphate buffered saline containing $0.75 \%$ bovine albumin, 100 units $/ \mathrm{ml}$ penicillin, $100 \mu \mathrm{g} / \mathrm{ml}$ streptomycin, and $250 \mu \mathrm{g} / \mathrm{ml}$ amphotericin B).

Equines were serosurveyed for West Nile virus from April to May 2008. Equines were selected from stables, paddocks, and roads. None had been vaccinated against West Nile virus or had any history of travel. They were bled from 


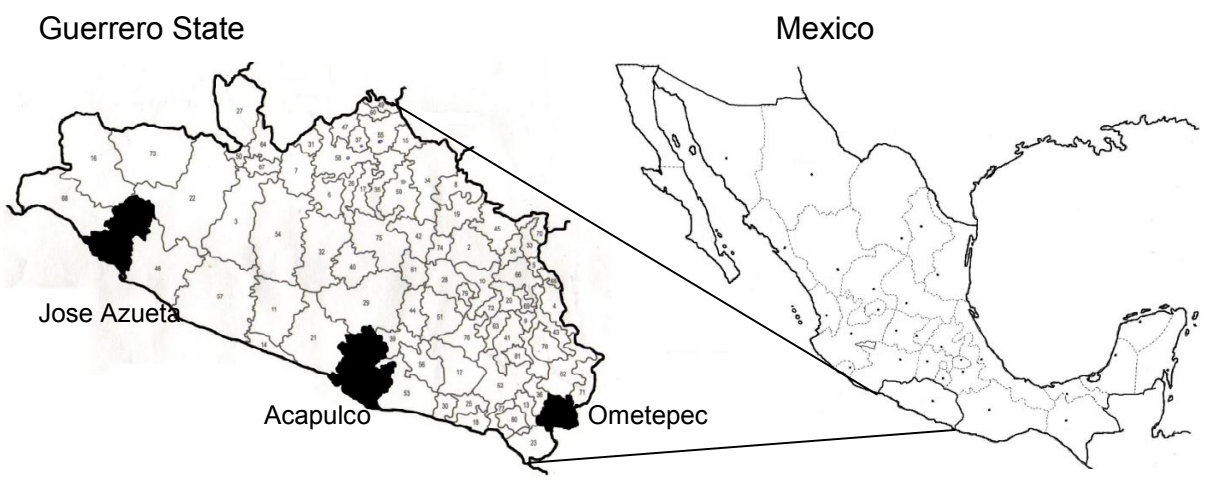

Fig. 1. Geographical location of West Nile virus surveys in Guerrero State, Mexico (INEGI 2012).

the jugular vein and blood samples immediately diluted using the field diluent described for birds.

Samples were placed on wet ice $\left(4^{\circ} \mathrm{C}\right)$ and transported to Laboratorio de Entomologia Medica, Universidad Autonoma de Nuevo Leon. The sera of bird and equine blood samples were separated by centrifugation at $1,500 \mathrm{rpm}$ for 10 minutes at $4^{\circ} \mathrm{C}$, then stored at $-70^{\circ} \mathrm{C}$.

Mosquito Collections. A CDC-style battery-powered backpack aspirator was used bimonthly from April 2008 to August 2009 to collect resting adult mosquitoes (Clark et al. 1994). Six 3-day collections were made at each of the three study locations. Mosquitoes resting outdoors near homes were aspirated during daylight hours. Selected sampling places included cattle stables, horse paddocks, natural resting shelters (i.e., tree and holes), rock piles, and swamps and lagoons with marginal vegetation. Mosquitoes collected each day were taken to Universidad de Guerrero, in Acapulco City, for genera and species identification aided by a chill table (Bioquip $®$, Gardenia, CA.) (Belkin et al. 1970, Clark-Gil and Darsie, 1983, Wilkerson et al. 1993, Ibañez-Bernal and Martinez-Campos, 1994, Darsie and Ward, 2005). Identified mosquitoes were grouped by sex and species into 2-ml Eppendorf $\circledast$ microtubes, ranging from two to 67 individuals in each group. Groups of mosquitoes were stored at $-70^{\circ} \mathrm{C}$.

Serological (ELISA) and Molecular (RT-PCR) Testing. An epitope blocking enzyme-linked immunosorbent assay (bELISA) (Blitvich et al. 2003a, b) was used at the Universidad Autonoma de Nuevo Leon to evaluate bird and equine serum samples for antibodies to West Nile virus. The ELISA was done with West Nile virus-specific monoclonal antibody 3.1112G (Vector Laboratories, Burlingame, CA). The ability of the host serum to block the binding of monoclonal antibody to West Nile virus antigen was compared with the blocking ability of host serum without West Nile virus antibody. Data were expressed as relative percentages, and inhibition values $\geq 30 \%$ were considered to indicate viral antibodies.

Mosquito sample pools were triturated for 45 seconds with a vortex mixer in a 5-ml round-bottomed polypropylene tube (Becton Dickinson, Franklin Lakes, NJ) that contained $1.5 \mathrm{ml}$ of diluent $(1 \times$ minimum essential medium supplemented with $2 \%$ fetal bovine serum, penicillin/streptomycin, L-glutamine, and non-essential amino acids) and four copper-coated steel shot particles (4.5- $\mathrm{mm}$ diameter, 0.177- 
$\mathrm{mm}$ caliber). Suspensions were centrifuged at $12,000 \mathrm{~g}$ for 10 minutes at $4^{\circ} \mathrm{C}$, and supernatants were collected. The QIAamp viral RNA Mini kit (Qiagen Inc., Valencia, CA) was used to extract total RNA from supernatants. Mosquito pools were tested using West Nile virus-specific primers developed and recommended by the United States Centers for Disease Control and Prevention for use in surveillance for West Nile virus (Gubler et al. 2000, Lanciotti et al. 2000). Complementary DNAs were generated using Superscript III reverse transcriptase (Invitrogen, Carlsbad, CA) and PCRs were done using GoTaq DNA polymerase (Promega, Madison, WI).

\section{Results}

A group of four (10\%) of the 40 bird sera showed West Nile virus antibodies when tested by blocking ELISA. Two of the latter seropositive birds were trapped in Acapulco, i.e., one Pitangus sulfuratus L. and one Trogon citreolus Gould, and the other two, one Gallus gallus domesticus L. and one Columbina minuta L., at Ometepec. All are resident bird species (Table 1). The 40 birds belonged to 10 orders, 14 families, and 20 species. The West Nile virus seropositive birds were in the Columbidae, Phasianidae, Trogonidae, and Tyrannidae families.

A total of 102 equine serum samples was collected from the three study sites. Nineteen (18.6\%) samples showed West Nile virus antibodies in birds at all sampling sites. Five (15.6\%) of 32 equines were seropositive in Acapulco, 11 $(10.3 \%)$ of 57 in Ometepec, and three $(23.1 \%)$ of 13 in José Azueta. Most seropositive equines $(89.5 \%)$ were horses, while the remaining $(10.5 \%)$ were donkeys, Equus asinus L. (Table 2).

A total of 4,854 female mosquitoes collected from the three study sites during all the backpack aspiration was used for molecular testing. Sixteen species and seven genera of Culicidae were found in the mosquito survey of Guerrero State. All 116 pools were tested for West Nile virus by RT-PCR (Table 3). Most mosquito species were Deinocerites pseudes Dyar (23), Uranotaenia lowii Theobald (23), and Uranotaenia pulcherrima Linch-Arribalzaba (14). None of the pools of mosquitoes tested by RT-PCR for West Nile virus was positive.

Table 1. Summary of Birds Collected in Guerrero State, Mexico, from 2007-2008 with Blood Serum Positive for West Nile Virus Antibodies by Blocking ELISA Technique

\begin{tabular}{|c|c|c|c|c|}
\hline $\begin{array}{l}\text { ID } \\
\text { no. }\end{array}$ & Locality & $\begin{array}{l}\text { Common name } \\
\text { (Species) }\end{array}$ & $\begin{array}{l}\text { Family } \\
\text { (Order) }\end{array}$ & $\begin{array}{c}\text { \% inhibition by } \\
\text { blocking ELISA }\end{array}$ \\
\hline A-11 & Ometepec & $\begin{array}{c}\text { Chicken } \\
\text { Gallus gallus domesticus }\end{array}$ & $\begin{array}{l}\text { Phasianidae } \\
\text { (Galliformes) }\end{array}$ & 70.11 \\
\hline A-19 & Ometepec & $\begin{array}{l}\text { Grown dove } \\
\text { Columbina minuta }\end{array}$ & $\begin{array}{l}\text { Columbidae } \\
\text { (Columbiformes) }\end{array}$ & 37.46 \\
\hline A-26 & Acapulco & $\begin{array}{c}\text { Great kiskadee } \\
\text { Pitangus sulphuratus }\end{array}$ & $\begin{array}{c}\text { Tyrannidae } \\
\text { (Passeriformes) }\end{array}$ & 38.64 \\
\hline A-33 & Acapulco & $\begin{array}{l}\text { Citreoline trogon } \\
\text { Trogon citreolus }\end{array}$ & $\begin{array}{c}\text { Trogonidae } \\
\text { (Trogoniformes) }\end{array}$ & 60.05 \\
\hline
\end{tabular}

b Inhibition values $\geq 30 \%$ are considered positive

${ }^{c} M A B$ is West Nile virus-specific 
Table 2. Summary of Equines Sampled in Guerrero State, Mexico, with Blood Serum Positive for West Nile Virus Antibodies by the Blocking ELISA Technique

\begin{tabular}{cccccc}
\hline Equine & Species & Study site & Age (y) & Sex & $\begin{array}{c}\text { \% inhibition by blocking ELISA } \\
\text { a }\end{array}$ \\
\hline $\mathrm{H}-7$ & E. caballus & Acapulco & 8 & Male & 58.92 \\
$\mathrm{H}-14$ & E. caballus & Acapulco & 9 & Male & 47.01 \\
$\mathrm{H}-17$ & E. caballus & Acapulco & 6 & Male & 34.71 \\
$\mathrm{H}-19$ & E. caballus & Acapulco & 7 & Female & 39.57 \\
$\mathrm{H}-21$ & E. caballus & Acapulco & 5 & Female & 53.50 \\
$\mathrm{H}-39$ & E. caballus & Ometepec & 11 & Male & 54.61 \\
$\mathrm{H}-43$ & E. caballus & Ometepec & 8 & Female & 74.59 \\
$\mathrm{H}-47$ & E. caballus & Ometepec & 1 & Male & 78.98 \\
$\mathrm{H}-51$ & E. caballus & Ometepec & 4 & Male & 52.76 \\
$\mathrm{H}-53$ & E. asinus & Ometepec & 3 & Female & 39.97 \\
$\mathrm{H}-63$ & E. caballus & Ometepec & 10 & Female & 76.22 \\
$\mathrm{H}-65$ & E. caballus & Ometepec & 4 & Male & 82.08 \\
$\mathrm{H}-73$ & E. asinus & Ometepec & 10 & Male & 74.14 \\
$\mathrm{H}-75$ & E. caballus & Ometepec & 10 & Male & 53.10 \\
$\mathrm{H}-78$ & E. caballus & Ometepec & 8 & Male & 85.28 \\
$\mathrm{H}-79$ & E. caballus & Ometepec & 11 & Male & 98.64 \\
$\mathrm{H}-90$ & E. caballus Jose Azueta & 10 & Male & 48.49 \\
$\mathrm{H}-96$ & E. caballus & Jose Azueta & 8 & Male & 38.46 \\
$\mathrm{H}-97$ & E. caballus Jose Azueta & 9 & Male & 35.12 \\
\hline
\end{tabular}

${ }^{a}$ Inhition values $\geq 30 \%$ are considered significant

${ }^{\mathrm{b}} \mathrm{MAB}$ is West Nile virus-specific

\section{Discussion}

More than 36,000 human cases of West Nile virus have occurred in the United States from 1999 to 2012 (CDC 2012). Despite the fact that the MexicoUSA border is $3,169 \mathrm{~km}$ long, it is surprising that only 11 human cases of West Nile virus have been registered in Mexico through 2012 (CONAVE 2012). Nevertheless, the zoonotic factors involved in West Nile virus ecology, e.g., birds, equines, and mosquitoes, have been found mostly along the northern states and along the Gulf of Mexico (Fernandez-Salas et al. 2003; Blitvich et al. 2003a,b; Elizondo et al. 2005; Ibarra-Juarez et al. 2012).

However, this serosurvey demonstrated the first evidence of West Nile virus enzootic circulation in Guerrero State where Acapulco, the second-most popular tourist beach in Mexico, is located. Results showed all study sites with West Nile virus antibodies in equines, e.g., Acapulco (15.6\%), José Azueta (23.1\%), and Ometepec (10.3\%) (Table 2). The West Nile virus seroprevalence was $18.6 \%$ in equines in Guerrero State. Horses seem to play an important role as a West Nile virus host-sentinel in Mexico; reports from North Mexico documented as much as $62.5 \%$ in Coahuila (Blitvich et al. 2003b) and $41.0 \%$ in Nuevo Leon states (IbarraJuarez et al. 2012). Bird sera tested by ELISA indicated West Nile virus seroprevalence from only two study sites, e.g., Acapulco (5.0\%) and Ometepec $(5.0 \%)$. Although all seropositive species were classified as resident birds, Guerrero State is part of the Central and Pacific flyways of migratory North American birds (BirdLife International 2012a,b). Thus, it would not be surprising if 
Table 3. Mosquito Pools Tested by RT-PCR for West Nile virus in Guerrero State in Coastal Mexico, 2008-2009. Data are combined numbers of all collections and study sites. All mosquitoes were negative for West Nile virus antibodies.

\begin{tabular}{lc}
\hline \multicolumn{1}{c}{ Species } & Number of pools \\
\hline Aedes podographicus Dyar and Knab & 1 \\
Aedes taeniorhynchus Wiedeman & 2 \\
Anopheles albimanus Wiedeman & 5 \\
Culex coronator Dyar and Knab & 1 \\
Culex erraticus Dyar and Knab & 6 \\
Culex erythrotorax Dyar & 1 \\
Culex interrogator Dyar and Knab & 3 \\
Culex nigripalpus Theobald & 9 \\
Culex quinquefasciatus Say & 3 \\
Culex spp. (damaged) & 11 \\
Deinocerites pseudes Dyar & 23 \\
Hemagogus equines Theobald & 1 \\
Mansonia induvitans Dyar and Shannon & 1 \\
Mansonia titillans Walker & 9 \\
Uranotaenia lowii Theobald & 23 \\
Uranotaenia pulcherrima Linch-Arribalzaba & 14 \\
Uranotaenia sapphirina Osten Sacken & 2 \\
Uranotaenia spp. (damaged) & 1 \\
\hline TOTAL & 116 \\
\hline
\end{tabular}

extended time-space sampling found migrant birds seropositive for West Nile virus on the Pacific Mexican coastline. Serological surveys have found migrant seropositive bird species in Tamaulipas and Yucatan states (Fernandez-Salas et al. 2003, Farfan-Ale et al. 2004).

Although none of the pools with 16 species and seven genera of Culicidae tested by RT-PCR was positive for West Nile virus, our survey in the field included some mosquito species previously found infected at other Mexican locations, e.g., Cx. nigripalpus and Cx. interrogator in Chiapas State (Ulloa et al. 2009), and Cx. quinquefasciatus in Nuevo Leon State (Elizondo-Quiroga et al. 2005, Ibarra-Juarez et al. 2012). The abundance of mosquitoes we trapped that feed on amphibians and reptiles i.e., De. pseudes and Ur. lowii, instead of bird-blood feeders such as $C x$ quinquefasciatus and related species (WRBU 2013) might explain the negative West Nile virus results.

In general, serological surveys of West Nile virus vectors and reservoirs are useful to assess emergence and re-emergence of this serious disease in localities suspected to be infected. The recent and unexpected outbreak of West Nile virus in Dallas, TX, during 2012 reminds us that West Nile virus maintains a silent circulation. Public health surveillance programs should include studies of zoonotic cycles.

\section{Acknowledgment}

We are very grateful to Mr. Henry Rupp for textual review. We also thank Mr. Esteban Díaz and Mr. Alejandro Gaitán for their endless support throughout writing of the manuscript. Financial support was provided by Mexico CONACYT, and we 
give special thanks to the Laboratorio Estatal de Salud Pública de Guerrero and the Universidad Autónoma de Guerrero.

\section{References Cited}

Belkin, J. N., S. J. Heinemann, and W. A. Page. 1970. The Culicidae of Jamaica (Mosquito Studies XXI). Contributions of the American Entomological Institute 6: 1.

BirdLife International. 2012a. Pacific Americas Flyway. Available at http://www.birdlife.org/datazone/userfiles/file/sowb/flyways/1_Pacific_Americ as_Factsheet.pdf. Accessed 28 December 2012.

BirdLife International. 2012b. Central Americas Flyway. Available at http://www.birdlife.org/datazone/userfiles/file/sowb/flyways/2_Central_Americ as_Factsheet.pdf. Accessed 28 December 2012.

Blitvich, B. J. 2008. Transmission dynamics and changing epidemiology of West Nile virus. Anim. Health Res. Rev. 9: 71-86.

Blitvich, B. J., R. A. Bowen, N. L. Marlenee, R. A. Hall, M. L. Bunning, and B. J. Beaty. 2003a. Epitope-blocking enzyme-linked immunosorbent assays for detection of West Nile virus antibodies in domestic mammals. J. Clinical Microbiol. 41: 2676-2679.

Blitvich, B. J., I. Fernandez-Salas, J. F. Contreras-Cordero, N. L. Marlenee, J. I. Gonzalez-Rojas, N. Komar, D. J. Gubler, C. H. Calisher, and B. J. Beaty. 2003b. Serologic evidence of West Nile virus infection in horses, Coahuila State, Mexico. Emerging Infectious Dis. 9: 853.

Bosch, I., F. Herrera, J.C. Navarro, M. Lentino, A. Dupuis, J. Maffei, M. Jones, E. Fernandez, N. Perez, J. Perez-Eman, A. E. Guimaraes, R. Barrera, N. Valero, J. Ruiz, G. Velasquez, J. Martinez, G. Comach, N. Komar, A. Spielman, and L. Kramer. 2007. West Nile virus, Venezuela. Emerging Infectious Dis. 13: 651.

Calisher, C. H., and E. A. Gould. 2003. Taxonomy of the virus family Flaviviridae. Advances in Virus Res. 59: 1-19.

Clark, G. G., H. Seda, and D. J. Gubler. 1994. Use of the "CDC backpack aspirator" for surveillance of Aedes aegypti in San Juan, Puerto Rico. J. Amer. Mosq. Cont. Assoc. 10: 119.

Clark-Gil, S. and R. F. Darsie. 1983. The Mosquitoes of Guatemala their Identification, Distribution and Bionomics with Keys to Adult Females and Larvae. Army Medical Research and Development Commant. 15: 151-284.

Comité Nacional para la Vigilancia Epidemiológica (CONAVE). 2012. Aviso epidemiológico Virus del Oeste del Nilo: Incremento de casos de infección por Virus del Oeste del Nilo en los Estados Unidos de América. Secretaría de Salud, México. Available at http://www.dgepi.salud.gob.mx/2010/PDFS/ ALERTAS/Aviso-VON-210812.pdf. Accessed 28 December 2012.

Control Disease Center (CDC). 2012. Statistics, Surveillance, and Control Archive, West Nile Virus. Available at http://www.cdc.gov/ncidod/dvbid/westnile/ surv\&control.htm. Accessed 28 December 2012.

Darsie, R. F. and R. A. Ward. 2005. Identification and Geographical Distribution of the Mosquitoes of North America, North of Mexico. University Press of Florida, Gainesville, FL.

Ebel, G. D., and A. P. Dupuis. 2001. Partial genetic characterization of West Nile virus strains, New York State, 2000. Emerging Infectious Dis. 7: 650. 
Elizondo-Quiroga, D., C. T. Davis, Fernandez-Salas, R. Escobar-Lopez, D. Velasco-Olmos, L. C. Soto-Gastalum, M. Aviles-Acosta, A. Elizondo-Quiroga, J. I. Gonzalez-Rojas, J. F. Contreras-Cordero, H. Guzman, A. Travassos da Rosa, B. J. Blitvich, A. D. Barret, B. J. Beaty, and R. B. Tesh. 2005. West Nile virus isolation in human and mosquitoes, Mexico. Emerging Infectious Dis. 11: 1449.

Estrada-Franco, J., R. Navarro-Lopez, D. W. Beasley, L. Coffey, A. S. Carrara, A. Travassos da Rosa, A. T. Clements, E. Wang, G. V. Ludwig, A. Campomanes-Cortes, P. Paz-Ramirez, R. B. Tesh, A. D. Barret, and S. C. Weaver. 2003. West Nile virus in Mexico: evidence of widespread circulation since July 2002. Emerging Infectious Dis. 9: 1604.

Farfán-Ale, J., B. J. Blitvich, M. Loroño-Pino, N. Marlenee, E. Rosado-Paredes, J. García-Rejón, L. Flores-Flores, L. Chulim-Perera, M. López-Uribe, G. PérezMendoza, I. Sánchez-Herrera, W. Santamaría, J. Moo-Huchim, D. Gubler, B. Cropp,C. H. Calisher, and B. J. Beaty. 2004. Longitudinal studies of West Nile virus infection in avians, Yucatan State, Mexico. Vector-Borne Zoonotic Dis. 4: 3-14.

Fernandez-Salas, I., J. F. Contreras-Cordero, B. J. Blitvich, J. I. Gonzalez-Rojas, A. Cavazos-Alvarez, N. L. Marlenee, A. Elizondo-Quiroga, M. A. Loroño-Pino, D. J. Gubler, B. C. Cropp, C. H. Calisher, and B. J. Beaty. 2003. Serologic evidence of West Nile virus infection in birds, Tamaulipas State, Mexico. Vector-Borne Zoonotic Dis. 4: 209-213.

García, M. E. 1981. Modificaciones al sistema de clasificación climática de Kôppen. $3 \mathrm{r}^{\mathrm{a}}$ ed. Universidad Nacional Autónoma de México, Instituto de Geografía, Distrito Federal, México.

Gobierno del Estado de Guerrero. 2012. Geografía. Available at http://guerrero.gob.mx/articulos/geografia/. Accessed 28 December 2012.

Gubler, D. J., G. L. Campbell, R. Nasci, N. Komar, L. Petersen, and J. T. Roehrig. 2000. West Nile virus in the United States: guidelines for detection, prevention, and control. Viral Immunol. 13: 469-475.

Hayes, E. B., N. Komar, R. S. Nasci, S. P. Montgomery, D. R. O'Leary, and G. L. Campbell. 2005. Epidemiology and transmission dynamics of West Nile virus disease. Emerging Infectious Dis. 8: 1167-1173.

Ibañez-Bernal, S., and C. Martinez-Campos. 1994. Clave para la identificación de mosquitos comunes en las áreas urbanas y suburbanas de la Republica Mexicana, (Diptera: Culicidae). Folia Entomol. Mexicana, México 92: 42-73.

Ibarra-Juarez, L., L. Eisen, B. G. Bolling, B. J. Beaty, B. J. Blitvich, R. M. SanchezCasas, Y. O. Ayala-Sulca, and I. Fernandez-Salas. 2012. Detection of West Nile virus-specific antibodies and nucleic acid in horses and mosquitoes, respectively, in Nuevo Leon State, northern Mexico, 2006-2007. Med. Vet. Entomol. 26: 351-354.

Instituto Nacional de Estadística y Geografía (INEGI). 2012. Mapa Digital de México. Available at http://www.inegi.org.mx/geo/contenidos/mapadigital/. Accessed 28 December 2012.

Kaufman, K. R. Bowers, and N. M. Bowers. 2005. Field Guide to Birds of North America. Houghton Mifflin Company.

Komar, N., and G. C. Clark. 2006. West Nile virus activity in Latin America and the Caribbean. Pan Amer. J. Public Health 2: 1-9.

Kramer, L. D., L. M. Styer, and G. D. Ebel. 2008. A global perspective on the epidemiology of West Nile virus. Annu. Rev. Entomol. 53: 61-81. 
Lanciotti, R. S., J. T. Roehrig, V. Deubel, J. Smith, M. Parker, K. Steele, and D. J. Gubler. 1999. Origin of the West Nile virus responsible for an outbreak of encephalitis in the northeastern United States. Sci. 286: 2333-2337.

Lanciotti, R., A. Kerst, R. Nasci, M. Godsey, C. Mitchell, H. Savage, N. Komar, N. Panella, B. Allen, K. Volpe, B. Davis, and J. Roehrig. 2000. Rapid detection of West Nile virus from human clinical specimens, field-collected mosquitoes, and avian samples by a TaqMan reverse transcriptase-PCR assay. J. Clinical Microbiol. 38: 4066-4071.

Lindenbach, B. D., H. J. Thiel, and C. M. Rice. 2007. Flaviviridae: The Viruses and Their Replication. Fields Virology. Lippincott Williams \& Wilkins, Philadelphia.

Morales, M. A., M. Barrandeguy, C. Fabbri, J. B. Garcia, A. Vissani K. Trono, G. Gutierrez, S. Pigretti, H. Menchaca, N. Garrido, N. Taylor, F. Fernandez, S. Levis, and D. Enria. 2006. West Nile virus isolation from equines in Argentina, 2006. Emerging Infectious Dis. 12: 1559-1561.

Medina, G., E. Sandoval, T. B. Rentería, G. López, A. De la Mora, and L. Pujol. 2008. West Nile virus detection by RT-PCR from mosquitoes in a locality of Baja California, Mexico. Revista Latinoamericana Microbiol. 50: 83-86.

Murray, K. O., E. Mertens, and P. Desprès. 2010. West Nile virus and its emergence in the United States of America. Vet. Res. 41: 67.

Peterson, R. T., and E. L. Chalif. 1993. A Field Guide to Mexican Birds. Houghton Mifflin Company.

Ralph C. J., G. R. Geupel, P. Pyle, T. E. Martin, D. F. De Sante, and B. Milá. 1996. Manual de Métodos de Campo para el Monitoreo de Aves Terrestres. U.S. Dep. Agric.

Rios-Ibarra, C., B. J. Blitvich, J. Farfan-Ale, J. Ramos-Jimenez, S. Muro-Escobedo, H. R. Martínez-Rodriguez, R. Ortiz-López, E. Torres-López, and A. M. RivasEstilla. 2010. Fatal human case of West Nile disease, Mexico, 2009. Emerging Infectious Dis. 16: 741.

Smithburn, K. C., T. P. Hughes, A. W. Burke, and J. H. Paul. 1940. A neurotropic virus isolated from the blood of a native of Uganda. Amer. J. Trop. Med. 20: 471-472.

Ulloa, A., H. Hann-Ferguson, J. Méndez-Sánchez, R. Danis-Lozano, M. CasasMartínez, J. G. Bond, J. C. García-Zebadúa, A. Orozco-Bonilla, J. A. JuárezOrdaz, J. Farfan-Ale, J. García-Rejón, E. P. Rosado-Paredes, E. Edwards, N. Komar, H. K. Hassan, T. R. Unnasch, and M. A. Rodríguez-Pérez. 2009. West Nile virus activity in mosquitoes and domestic animals in Chiapas, Mexico. Vector-Borne Zoonotic Dis. 9: 555-560.

Vried, M. M. 1988. Guía de Aves de Jaula. Grijalbo, España.

Walter Reed Biosystematics Unit (WRBU). 2013. Mosquito Identification Resources. Available at http://wrbu.si.edu/VecIDResourcesMQ.html. Accessed 28 December 2012.

Wilkerson, R. C., D. Strickman, I. Fernandez-Salas, and S. Ibañez-Bernal. 1993. Clave llustrada para la Identificación de las Hembras de Mosquitos Anofelinos de México y Centroamérica (Díptera: Culicidae). Secretaría de Salud, México. 
